\title{
Factors affecting the variability in home range size and distribution in European bison in the Polish and Belarussian parts of the Bialowieża Forest
}

\author{
Małgorzata KRASIŃSKA, Zbigniew A. KRASIŃSKI and Aleksei N. BUNEVICH
}

Krasińska M., Krasiński Z. A. and Bunevich A. N. 2000. Factors affecting the variability
in home range size and distribution in European bison in the Polish and Belarussian parts of the Białowieża Forest. Acta Theriologica 45: 321-334.

The size and spatial distribution of home ranges of the European bison Bison bonasus (Linnaeus, 1758) in the Polish and Belarussian parts of the Białowieża Forest were studied in the years 1993-1998. In this period, 28 bison (18 males and 10 females) aged 4-10 years, including $20(15,5)$ from the Polish part of the Białowieża Forest and $8(3,5)$ from the Belarussian part, were radio-collared. The mean size of winter home ranges of bulls was $10.7 \mathrm{~km}^{2}$ (range $0.8-32.2, n=25$ ) while that of cows was $7.9 \mathrm{~km}^{2}$ (range $0.7-34.3, n=15$ ), difference between the sexes not being significant. The size of winter home ranges was significantly correlated with the duration of snow cover and with the mean daily temperature in winter $\left(R^{2}=0.311, p=0.001\right)$. Long-lasting snow cover and low temperatures significantly limited bison mobility in the forest. In the snow-free season, the mean size of home ranges of bulls was $69.5 \mathrm{~km}^{2}$ (range 29-151.6) and that of cows was $68.8 \mathrm{~km}^{2}$ (range 45.4-97.5), the difference not being statistically significant. The size of bulls' home ranges in the snow-free period was related to their age. The mean size of home ranges of younger adult bulls was $44.0 \mathrm{~km}^{2}$, being significantly smaller than the ranges of older adult bulls $\left(84.3 \mathrm{~km}^{2}\right)$ and cows. European bison used their ranges unevenly and showed individual spatial fidelity in subsequent years. Home ranges of the European bison of both sexes were not defended and overlapped extensively. Food abundance of remarkably diverse habitats (forest, meadows) had a significant effect on the size of bison home ranges. In August-October, home ranges of cows from the Polish populations penetrating the forest averaged 45.5 $\mathrm{km}^{2}$ and were significantly larger than the ranges of cows from the Belarussian population foraging on meadows $\left(24.3 \mathrm{~km}^{2}\right)$.

Mammal Research Institute, Polish Academy of Science, 17-230 Białowieża, Poland, e-mail: mkrasin@bison.zbs.bialowieza.pl (MK); Białowieża National Park, 17-230 Białowieża, Poland (ZAK); State National Park "Belovezhskaya Pushcha", Brestskaya oblast, Kameneckii raion, 225063 p/o Kamenyuki, Belarus (ANB)

Key words: Bison bonasus, home range size, overlap, radio-tracking

\section{Introduction}

Two isolated populations of lowland European bison Bison bonasus bonasus (Linnaeus, 1758), live in the Białowieża Forest, which since World War II has been divided by an international border. In the Polish part, the reintroduction of a free-ranging herd was initiated in 1952 and continued until 1966 (Krasiński 1983). 
In the Belarussian part, however, free breeding of bison has a complicated history. It was launched in 1953 with bison of Lowland-Caucasian line, which were subsequently removed and replaced by pure lowland bison. By 1970, the population of lowland bison in the Belarussian part of the Forest was reestablished and its structure left undisturbed (Korochkina and Kochko 1982). Since 1980, the two herds have lived in the Białowieża Forest separated from each other by a fence built along the border on the Belarussian side. Earlier, there were reports of sporadic movements of bulls from the Belarussian herds, but the animals were caught and not allowed to come into contact with the Polish population (Krasiński 1967).

In the years 1976-1990 in the Polish part of the Białowieża Forest, studies on the size of home ranges of bison were conducted via direct observations of individuals from both sexes marked with a number frozen on their skin by liquid nitrogen. Marked bison belonged to one winter aggregation, which in the snow-free season occupied the southern part of the population area. Thus, the results could not be fully representative for the whole population (Krasińska et al. 1987, Krasińska and Krasiński 1995).

Earlier studies on spatial distribution of European bison populations allowed determination of the area occupied by the population in various periods of development (Korochkina 1973, Krasiński 1978), and enabled detection of changes in bison distribution within the Białowieża Forest at the turn of the 1980s and 1990s (Bunevich 1994, Krasińska and Krasiński 1994, Krasiński et al. 1994, Krasińska et al. 1997a).

A comparison between the populations of European bison inhabiting the Polish and the Belarussian parts of the Forest showed that the species characteristics of bison included a social structure (group types) and a spatial structure. However, group size and habitat use depended on food abundance and its availability, and differed in these two parts of the Forest (Krasiński et al. 1994, Krasińska et al. 1997a, b).

The introduction of telemetric studies in 1993 opened the possibility of comparative studies on the spatial distribution of home ranges of the European bison living in the different habitats of the Polish and Belarussian parts of the Białowieża Forest. The aim of this study, based on radio-collared bison, was to investigate the relationship between the size of bison home ranges and animals' sex, age, and the role of habitat differences in these two parts of the Forest, as well as to examine spatial distribution of ranges.

The study tested the following hypotheses set up on the basis of earlier results: (1) The relationships created in large mixed aggregations in winter may affect spatial distribution of bison home ranges and group area in the Białowieża Forest; (2) Home-range size of bulls can be age-dependent; (3) Bulls and cows may show strong spatial fidelity in subsequent years; (4) Home ranges of males and females are not defended and may overlap extensively; (5) Food abundance of different habitats (forest, meadow) may have a significant effect on the size of bison home ranges. 


\section{Study area and characteristics of populations}

In 1997, the Białowieża Forest covered an area of $1468 \mathrm{~km}^{2}$. Its western part $\left(594 \mathrm{~km}^{2}\right)$ lies within Polish borders; the eastern part $\left(874 \mathrm{~km}^{2}\right)$ in Belarus (Sokołowski 1997). In the Polish part, forests cover $96 \%$ of the area, the remainder consisting of fields, meadows, and roads. In the Białowieża Forest, the natural forage of ungulates is supplemented with managed meadows and reforested areas covered in grass, called feeding glades, covering a small part of the Forest (meadows $0.1 \%$, feeding glades $0.2 \%$ of the forest area). In the last twenty years forest meadows have not been utilized. Deciduous forests are predominant (mixed, fresh and moist deciduous forests), covering $58.3 \%$ of the forest area. In coniferous habitats, mixed coniferous forest is found to dominate (18.2\%). Most of the tree stands of the Polish part of the Białowieża Forest are dominated by spruce Picea abies $(31.5 \%$ of the area) and pine Pinus silvestris (17.6\%). Tree stands dominated by oak Quercus robur and hornbeam Carpinus betulus cover $15.8 \%$ of the area, birch (Betula verrucosa and B. pubescens) $9.4 \%$, alder Alnus glutinosa 19.5\%, ash Fraxinus excelsior 4.5\%, other deciduous tree species eg Norway maple Acer platanoides, lime Tilia cordata, aspen Populus tremula cover $1.7 \%$.

The ungulates living there exert a substantial effect on the Forest flora. In autumn 1998, the number of ungulates living in the Polish part of the Forest (without strict reserve of Białowieża National Park) was determined to be: red deer 1600 , roe deer 1000, moose up to 20 (estimated), wild boar 1900 (Kossak 1998).

In the Belarussian part, forest covers $89 \%$ of the territory. Most common are tree stands with a predominance of coniferous species which cover $69 \%$ of the forest area. These include pine $(58 \%)$ and spruce $(11 \%)$. Deciduous forests occupy only $12.5 \%$ of the forest area. In the northern part and in the south, fresh coniferous forest stands can be found while the central part is covered in mixed coniferous and deciduous forests. Open areas (11\% of the Forest) are an important supplement of feeding base for ungulates (Jurkevich and Geltman 1965). In 1998, in the Belarussian part of the Forest, the number of ungulates was estimated at: red deer 1700 , roe deer 600 , moose 40 , wild boar 900 (unpublished data of the State National Park "Belovezhskaya Pushcha").

The two parts of the Forest are not only different in habitats but are also exploited differently by people. In the Polish part of the Forest, $105 \mathrm{~km}^{2}$ are occupied by the Białowieża National Park, including $47.5 \mathrm{~km}^{2}$ by a strict reserve. The remaining Polish part consists of exploited forest. The whole Belarussian part is the State National Park (not exploited commercially).

The number of European bison in the Polish population ranged from 251 in 1993 to 298 in 1998, while in the Belarussian part of the Forest there were from 308 bison in 1993 to 238 in 1998. Density of bison in the Polish part in that period ranged between $4.0-5.0$ bison $/ 10 \mathrm{~km}^{2}$, and in the Belarussian part 2.5-3.5/10 $\mathrm{km}^{2}$. In the years $1993-1998$, in the Polish and Belarussian parts of the Forest the main part of the population (mixed groups and most bulls) lived in the area covering approximately $60 \%$ of the Forest in the snow-free period, with bulls being encountered in the whole Forest (Bunevich 1991, 1994, Krasińska and Krasiński 1994, Krasińska et al. 1997a).

European bison are gregarious animals; there are two basic units of bison populations: bull groups and mixed groups (Krasiński 1978). In both bison populations, bull groups usually contain $2-3$ individuals. More than half of the males live as solitary individuals. The mean size of mixed groups in the Polish population was 13.4 individuals, in the Belarussian - 21 individuals. In both populations over $80 \%$ of groups inhabiting the forest contain up to 20 animals. The largest groups are encountered in the Belarussian part in open areas (up to 140 individuals), their size being significantly larger than the size of groups inhabiting both parts of the Forest (Bunevich and Kochko 1988, Krasińska et al. 1997b). In both Polish and Belarussian parts of Białowieża Forest, European bison are provided with abundant supplementary fodder in winter (hay, clover, beet roots).

During the analysed winters (1992/93 - 1997/98), the mean daily temperature (from 1 December to $31 \mathrm{March})$ ranged from $-6.22^{\circ} \mathrm{C}(1995 / 96)$ to $0.10^{\circ} \mathrm{C}(1994 / 95)$, and the snow-cover period lasted from 24 days (1994/95) to 122 days (1995/96). During the 6-year study, only one severe and frosty winter with long-lasting snow was noted (1995/1996). In the years 1993-1998, during the vegetative season (1 May - 31 October) in the Forest, weather conditions did not differ between the years. The mean daily temperature in this period varied slightly among years, from 14.1 to $15.4^{\circ} \mathrm{C}$. Seasonal sum of rainfall was the lowest in $1996(263 \mathrm{~mm})$ and the highest in the years 1995 and 1998 (464 and $465 \mathrm{~mm}$ ). 


\section{Material and methods}

In the years 1993-1998, 28 bison aged 4-10 years (18 males, 10 females) including $20(15,5)$ from the Polish part of the Białowieża Forest and $8(3,5)$ from the Belarussian part, were radio-collared. The radiocollars were made by LOTEK Engineering Inc., Canada. The animals were collared in winter. They were immobilized by Immobilon/Revivon using a pneumatic gun Telinject. The time of transmitter's work ranged from 1 month to 3 years. The maximum audibility of signals was obtained at a distance of $3-5 \mathrm{~km}$ and was weather-dependent.

Radio-collared bison were located 2-3 times a week throughout the year. The radio-collared bulls were divided into two groups: (1) younger adult bulls aged 5-6 years, which did not take part in reproduction and (2) older adult bulls aged 7-9 years. Three bulls ( 2 in the Polish part, and one in the Belarussian part) lived on the peripheries of the Forest in autumn, winter and spring. Those 3 bulls were called 'peripheral'. All radio-collared cows were adult (5-10 year old).

Data analysis was conducted in two markedly different periods of the population life cycle: (1) gathering at winter feeding sites and (2) free roaming in other seasons. In winter, bison gather at feeding sites, but wander over the Forest from spring to autumn. While free roaming, they use the natural food resources of the forest in a way specific to this species. In winter, all radio-collared bulls from the Polish population were living solitarily or in aggregations of bulls, periodically they were found in large mixed aggregations as well. Bulls from the Belarussian population are members of large mixed aggregation only, except of bull No 33 in winter 1997/98, when this bull was solitary, living outside of forest border. In winter, all radio-collared cows were living in large mixed aggregations consisting of $70-100$ bison in the Polish population, and $25-80$ bison in the Belarussian population. In the snow-free period, radio-collared bulls were solitary or in small groups of $2-3$, and seasonally were members of mixed groups. In this period all radiocollared cows were living in mixed groups, consisting of 7-15 individuals (in the Polish population) and 2-15 bison living in forest habitats of the Belarussian part of Forest. Since additional food affects spatial structure and distribution of bison during the winter, we could not compare the size and distribution of winter home ranges with ranges in the snow-free period.

The winter period lasted from 1 December to 31 March, while the snow-free period lasted from 1 April to 30 November of a given year. The latter included the vegetative season of the Forest flora (May-October). Data were also analysed in the period prior to the rut (May-July) and in the rutting season (August-October). In total, 2225 localizations of cows and 2212 localizations of bulls were obtained. For analysis we used data obtained from $24(14,10)$ bison, including $8(3,5)$ from the Belarussian population localized for at least one season. The size of home ranges in the snow-free season was determined based on 73-120 localizations of one bison in a given season. Six cows were subject to observation for 2 consecutive years, one for 3 years, and one for 4 years (after transmitters' change), and the remaining two for 1 year each. Three bulls were observed for 3 consecutive years, two for 3 years, two for 3 seasons and the other 13 for one season only. Winter home ranges are based on 45-55 localizations of each bison during one winter period.

All calculations of home range size, and the overlap between pairs of bison and spatial distribution of home ranges were made with Tracker software (A. Angerbjörn, Radio Location System, Huddinge Sweden) for $100 \%$ MCP. For habitat description, meadows, grass-covered deforested glades, clearcuts and young plantations up to 10 years, were defined as open areas.

Climatic data concerning the Białowieża Forest were collected at the weather station situated in the middle of the Białowieża Glade. Snow-cover duration was estimated by summing up permanent, at least five days long, snow-cover periods.

\section{Results}

\section{Winter home ranges}

In both populations the mean winter home range of bulls was $10.7 \mathrm{~km}^{2}$ and that of cows $7.9 \mathrm{~km}^{2}$ and there was not significant difference between sexes (Table 1). 
Table 1. Average size (SD, range) of European bison home ranges (in $\mathrm{km}^{2}$ ), studied by radio-tracking in Białowieża Forest in 1992/93-1997/98.

\begin{tabular}{|c|c|c|c|c|}
\hline \multirow[t]{2}{*}{ Group of animals } & \multirow{2}{*}{$\begin{array}{l}\text { Number } \\
\text { of home } \\
\text { ranges }\end{array}$} & \multicolumn{3}{|c|}{$\begin{array}{l}\text { Minimum Convex Polygon, } \\
100 \% \text { of localizations }\left(\mathrm{km}^{2}\right)\end{array}$} \\
\hline & & Mean & SD & Range \\
\hline \multicolumn{5}{|c|}{ Winter (1 December - 31 March) } \\
\hline Females & 15 & 7.9 & 10.0 & $0.7-34.3$ \\
\hline Males & 25 & 10.7 & 11.4 & $0.8-32.2$ \\
\hline \multicolumn{5}{|c|}{ Spring-autumn (1 April - 30 November) } \\
\hline Females & 20 & 68.8 & 16.1 & $45.4-97.5$ \\
\hline Males (all) & 19 & 69.5 & 31.5 & $29.0-151.6$ \\
\hline Males 5-6 yr old & 7 & 44.1 & 11.9 & $29.0-58.0$ \\
\hline Males 7-9 yr old & 12 & 84.3 & 29.9 & $57.2-151.6$ \\
\hline \multicolumn{5}{|c|}{ Prior to rut (1 May - 31 July) } \\
\hline Females in the Polish part & 12 & 35.3 & 16.4 & $16.2-69.6$ \\
\hline Females in the Belarussian part & 8 & 41.8 & 10.4 & $28.2-56.6$ \\
\hline Males (peripheral ones excluded) & 15 & 26.0 & 9.2 & $10.9-40.1$ \\
\hline Peripheral males & 2 & 110.6 & 27.4 & $91.2-129.9$ \\
\hline \multicolumn{5}{|c|}{ Rutting season (1 August - 31 October) } \\
\hline Females in the Polish part & 12 & 45.5 & 12.8 & $23.1-71.6$ \\
\hline Females in the Belarussian part & 8 & 24.3 & 9.0 & $12.8-38.0$ \\
\hline Males (all except for peripheral) & 15 & 35.3 & 11.5 & $29.3-57.7$ \\
\hline Males 5-6 yr old & 6 & 30.5 & 9.2 & $18.4-40.7$ \\
\hline Males 7-9 yr old & 11 & 38.5 & 13.2 & $20.0-57.7$ \\
\hline
\end{tabular}

The size of cows' winter home ranges is also the size of ranges of larger mixed aggregations, consisting of 70 to 100 bison in the Polish population, and 25-80 in the Belarussian population. During one winter, radiocollared bulls were living solitarily as well as in bull aggregations or mixed aggregations. At this time radio-collared cows living in mixed aggregations concentrated around one feeding site, while bulls visited several feeding sites situated at a distance of 1-4 km.

Multiple regression analysis between the size of winter home ranges, and the duration of snow cover and daily temperature as independent variables, proved significant $\left(R^{2}=0.311, p=0.001, n=40\right.$, Fig. 1$)$. The variability of the size of winter home ranges were shaped more by snow cover (semipartial correlation squared $\left.s r^{2}=0.21\right)$, and less by the daily temperature $\left(s r^{2}=0.10\right)$. Thus, snow cover significantly limited bison mobility in the forest. The smallest winter ranges were recorded during the frosty winter of 1995/96 with deep and long-lasting snow cover, whereas the largest in the mild winter of 1994/95 with little snow (Fig. 2). 


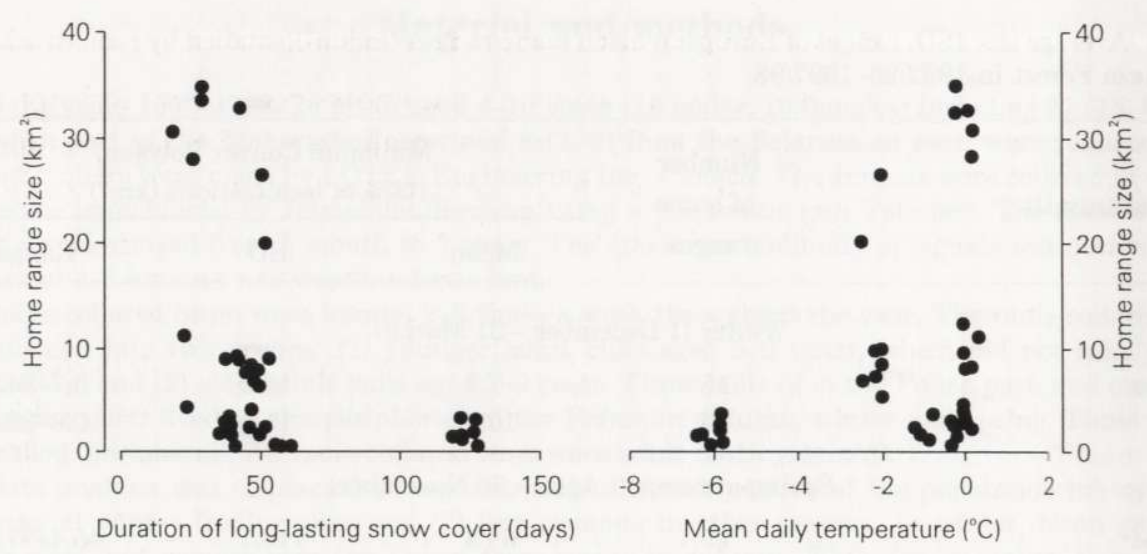

Fig. 1. Relationships between home ranges size of European bison in winter (1 December - 31 March) and the duration of snow cover and mean daily temperature in the Białowieża Forest (1992/93 1997/98). Each point denotes a home range of an animal in one winter season.
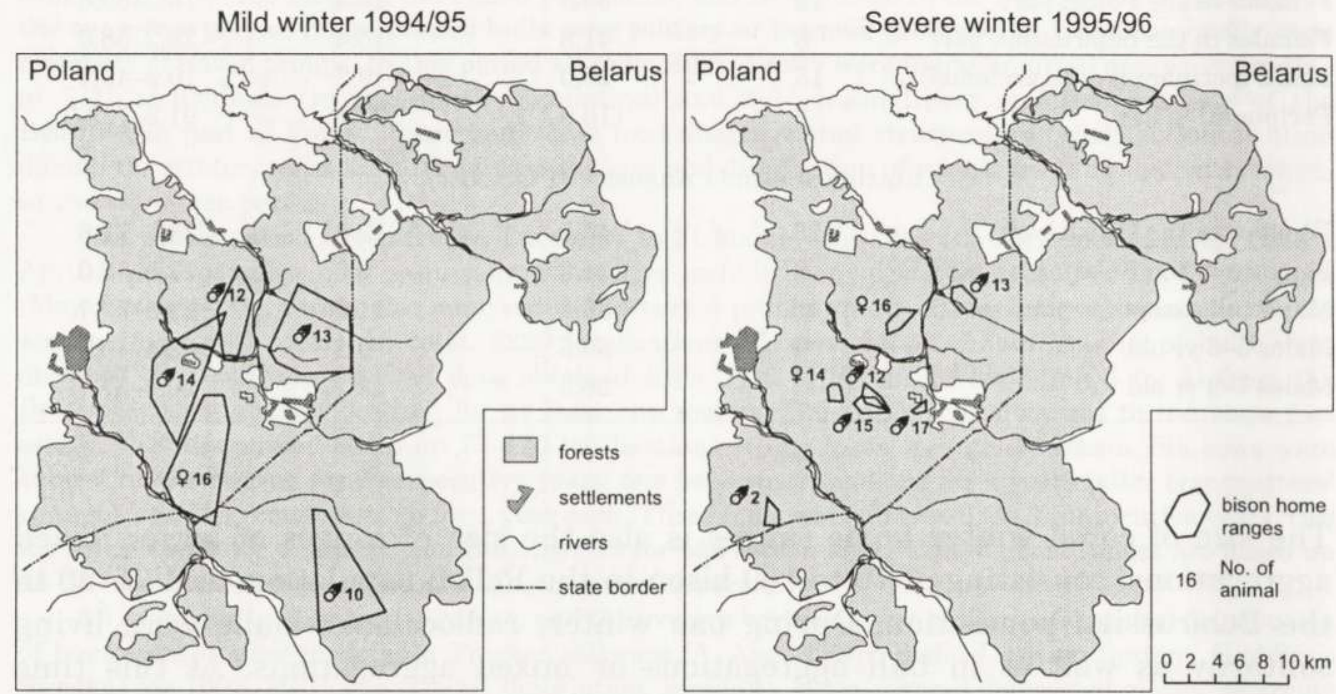

Fig. 2. Comparison of home range size of European bison during the mild (1994/95) and severe (1995/96) winters (1 December - 31 March) in the Białowieża Forest.

Worth noting is the fact that of radio-collared bison observed for longer than one winter season, in both part of the Białowieża Forest, all cows $(n=9)$ and bulls $(n=9)$ returned to the same feeding sites in 2-4 successive winters, except for bull No 33 from the Belarussian population, which moved beyond the Forest, spent winter period there and was lost during the following spring. 


\section{Home ranges in the snow-free period}

The home range sizes of bulls and cows in the snow-free period did not differ statistically, the mean values being $69.5 \mathrm{~km}^{2}$ for males and $68.8 \mathrm{~km}^{2}$ for females (Table 1). In spite of the fact that all radio-collared bulls were living solitarily or in groups of 2-3, all cows were members of mixed groups consisting of several individuals (up to 15 in the forest habitats) in both populations. No statistically significant differences were found between the size of the home ranges of bulls and cows within Polish and Belarussian populations, nor between individuals of the same sex coming from both populations. Also, home ranges of cows and older adult bulls did not differ significantly statistically in size. The size of cows' home ranges is also the size of mixed groups' ranges. Since the size of one mixed group changed several times during one season, analyzing the correlation between the size of a mixed group and the size of ranges was not possible.

The size of home ranges of bulls in the snow-free period was dependent on their age (Fig. 3). The mean home range of younger adult bulls was $44.0 \pm 11.9 \mathrm{~km}^{2}$, being significantly smaller than the range of older adult bulls $84.3 \pm 30 \mathrm{~km}^{2}$ (Mann-Whitney $U$-test $U=82, p=0.001$ ) and cows $(U=125, p=0.002)$.

In the Polish population, the largest home ranges were occupied by two peripheral bulls ( 136.5 and $151.6 \mathrm{~km}^{2}$ ). The largest bull range in the Belarussian population covered $85.8 \mathrm{~km}^{2}$. The maximum ranges of cows in the Polish and Belarussian populations were similar $\left(97.5 \mathrm{~km}^{2}\right.$ and $96.4 \mathrm{~km}^{2}$, respectively).

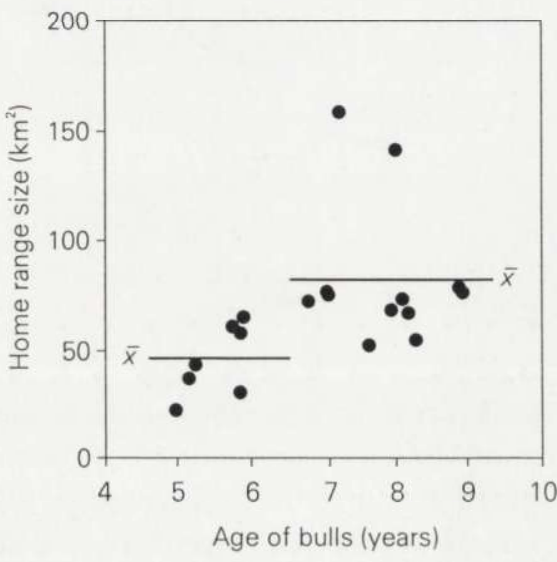

Fig. 3. Home range size of male bison in spring-autumn (1 April - 30 November) in relation to their age. Each point denotes a home range of an animal in one season. Lines mark mean values bulls $5-6$ years (not participating in reproduction) and bulls 7-9 year old (taking part in reproduction).

Radio-collared bison observed for a few consecutive years occupied home ranges situated in the same parts of the Białowieża Forest, although their sizes could vary (Fig. 4). On average, the ranges of cows in consecutive years overlapped in $87.2 \%$ (range 67.9-99.2\%) and those of males in $91.4 \%$ (range $85.5-100 \%$ ). Thus, bison showed spatial fidelity, and in subsequent years they were found in the same parts of the Forest.

In the Polish part of the Forest, in the snow-free season, the bison coming from winter aggregation located in forest compartment 391 penetrated the central and northwestern parts of the Forest, while those from aggregation in comp. 422 the southwestern and central parts (Fig. 5). In the Belarussian part of the Forest, the bison from winter aggregation in comp. 680 penetrated the southeastern and central parts of the Forest, while those from aggregation in comp. 201 - the central 

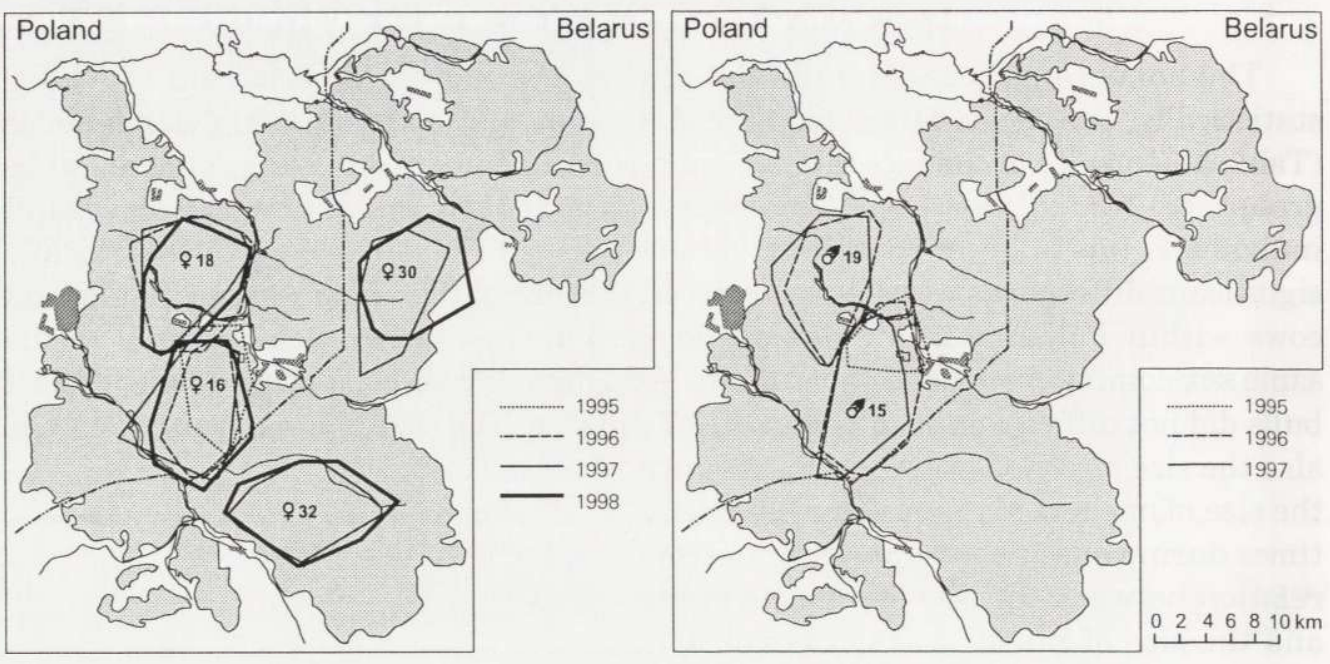

Fig. 4. Fidelity of females and males of European bison to their spring-autumn home ranges (1 April 30 November) in subsequent years. Legend to the map as in Fig. 2.

part (Fig. 5). Home ranges of bulls coming from the same winter feeding sites overlapped in the snow-free season in $77 \%$, on average (range 51-83\%). Home ranges of cows belonging to the same winter aggregation in the snow-free period overlapped in $70 \%$, on average $(62-77 \%)$ in both parts of the Forest. The home ranges of bulls and cows from the same winter aggregation, in the snow-free period, overlapped in $62 \%$, on average $(19-100 \%)$. This indicates that in the snow-free period bulls and cows coming from the same winter aggregation inhabit mainly the same part of the Forest. Home ranges of bison coming from different feeding sites overlapped slightly in the case of bulls $(0-16 \%)$, while in the case of cows the overlap was very rare; only one case was noted $(7 \%)$. Therefore, interspecific relationships created during the period of 4-5 months spent at winter feeding sites have an effect on spatial distribution of summer ranges of bison coming from various feeding sites.

Based on the localizations of radio-collared bison of both sexes from the same winter aggregation, it was estimated that, in the same spring-autumn period, the area of one part of the population consisting of 50-60 individuals ranged from 90 to $228 \mathrm{~km}^{2}$, in different years of the study, in both parts of the Forest.

The size of bison home ranges during the vegetative season in the Forest was not significantly correlated with the mean daily temperature, nor with the sum of rainfall at that time $(r=0.186, p=0.733$ for temperature, and $r=0.110, p=0.563$ for rainfall).

We analysed the size of bison home ranges in the rutting season and the period prior to rut. The period prior to rut covers spring and the beginning of summer (1 May - 31 July). At that time, mixed bison groups lived mainly in woodland in both 

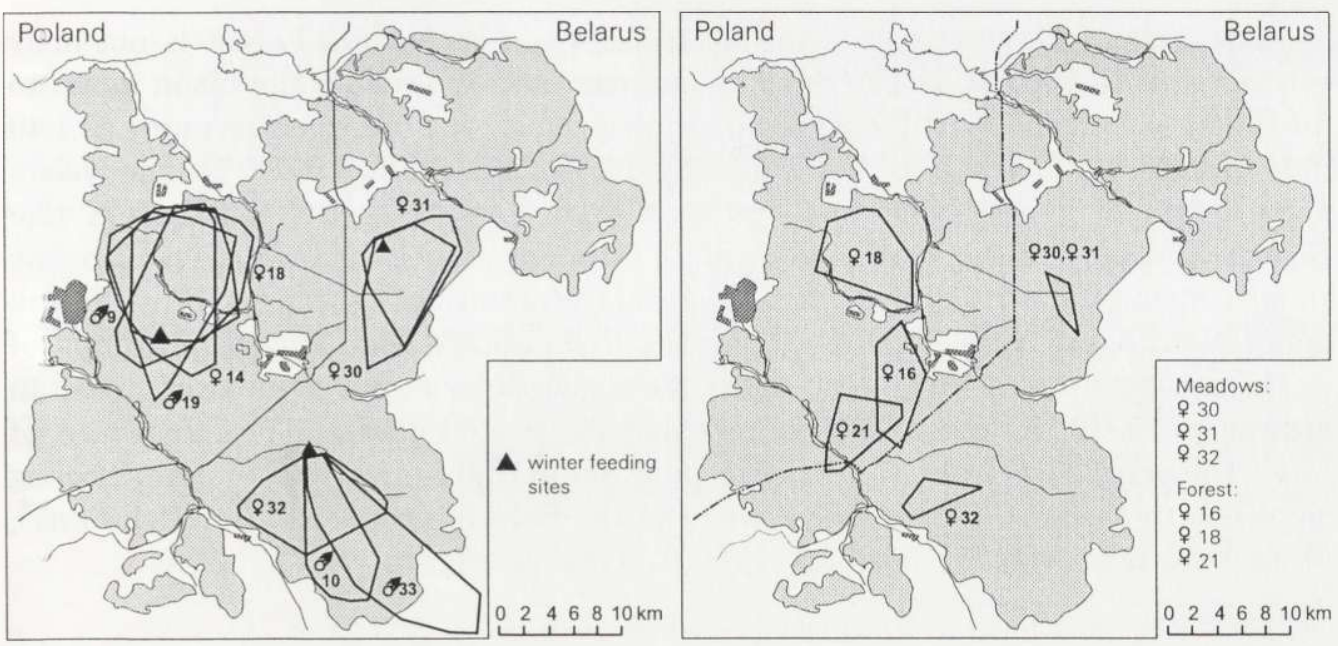

Fig. 5. Spatial distribution of the spring-autumn home ranges (1 April - 30 November) of two to four European bison coming from the same winter aggregations (aggregations formed at winter feeding sites located in the forest compartment 391 in the Polish part of the BF, and in compartments 201 and 608 in the Belarussian part of the Forest. Legend to the map as in Fig. 2.

Fig. 6. Comparison of home ranges sizes of female European bison foraging in forest (Polish part of BF) and those foraging in meadows (Belarussian part). Data for 15 August - 15 October 1997. Legend to the map as in Fig. 2.

parts of the Forest. The mean home range of cows of the Belarussian population was $41.8 \mathrm{~km}^{2}$, being larger than that of cows in the Polish part of the Forest 35.3 $\mathrm{km}^{2}$, the differences being not significant (Table 1). Statistically significant differences were found between the sizes of pre-rut home ranges of two peripheral bulls from the Polish population (mean $=110.6 \mathrm{~km}^{2}$ ), and the remaining bulls (mean $=26.0 \mathrm{~km}^{2}$; Mann-Whitney $U$-test: $U=30, p<0.01$; Table 1 ).

The rut lasts from 1 August to 31 October. The mean home ranges of bulls (without peripheral males) during the rut was $35.3 \mathrm{~km}^{2}$, and being significantly larger than the pre-rut home ranges (Mann-Whitney $U$-test: $U=170, p<0.01$; Table 1). The largest rut home ranges were occupied by cows from the Polish population (on average $45.5 \mathrm{~km}^{2}$ ). They were significantly larger compared with the rut home ranges of younger bulls ( $U=60, p<0.02$; Table 1 ). The sizes of rut home ranges of the two age groups of bulls were not significantly different. During the rut, in both populations, home ranges of the radio-collared cows coming from different winter aggregations did not overlap. Rut home ranges of cows and bulls from the same winter aggregation overlapped, on average, in 18\% (range 4-100\%), and those of cows and bulls from different winter aggregations also in 18\% (0-96\%). Rut home ranges of bulls belonging to the same aggregation overlapped in $35 \%$ (0-67\%), while those of bulls from different winter aggregations only in 10\% (0-25\%). 
The August-October period in bison life in the Białowieża Forest is not only connected with the rut. In the Belarussian part, it is the time when bison move to meadows to feed and form large mixed groups, whose size can reach as many as 140 individuals (Bunevich and Kochko 1988, Krasiński et al. 1994). In the years 1994-1998 (August-October), 5 radio-collared cows were investigated in the Belarussian part of the Forest, allowing a comparison between the sizes of home ranges during their foraging on meadows and the sizes of cows' ranges in the Polish population, living in forest. Cows from the Polish population stayed in groups of $7-15$, moving only in the forest. Cows from the Belarussian population lived in groups of 25-70, foraging on meadows and deforested glades. The mean size of home ranges of cows from the Polish population in that period was $45.5 \mathrm{~km}^{2}$, being significantly larger than those of cows from the Belarussian population $\left(24.3 \mathrm{~km}^{2}\right.$; Mann-Whitney $U$-test: $U=88, p<0.001$; Table 1, Fig. 6).

\section{Discussion}

Bison have been provided supplemental food since the 16th century (Kartsov 1903, Hedemann 1939). At present bison are provided with hay at 19 permanent feeding sites in both parts of the Białowieża Forest (Krasiński et al. 1994). Thus, winter period is no longer a critical time in the life of the population. Permanent access to high quality hay delimits natural mortality, but at the same time leads to a few months' bison concentration around feeding sites, which may adversely affect the animals' health. In earlier studies (1976-1990), the size of winter ranges was determined only for bulls coming from one winter feeding site (mean $=4.3 \mathrm{~km}^{2}$; Krasińska and Krasiński 1995). It was smaller than the mean size of winter home ranges of radio-collared bulls, but still within the ranges of variability. In this study, larger winter home ranges of bulls than those of cows indicate that males are more mobile.

The studies carried out in the years 1976-1993 revealed that the size of the wintering area of the bison population living in the Polish part of the Białowieża Forest was positively correlated with the mean daily temperature in winter and significantly negatively correlated with the duration of permanent snow cover (Krasińska and Krasiński 1994). Likewise, in our study the size of winter home ranges of radio-collared bison was correlated with weather conditions in winter. The study based on radio-collared bison localization confirmed earlier assumptions (Krasińska and Krasiński 1994, 1995) that low temperature and duration of snow cover significantly delimited bison's roaming during winter. Worth noting is the fact that during mild winters with little snow, bison prefer natural forage such as the bark of cut-down deciduous trees (eg aspen), or meadows and winter crops in fields beyond the Forest, thus they can be dispersed across a larger area.

Since the additional food affects the size and spatial distribution of winter home ranges, we cannot compare winter ranges with those in the snow-free period. Furthermore, it was not possible to analyse a relationship between the size of bison 
groups and the size of their home ranges, since one mixed group changed several times their composition during one season. Worth noting is the fact that all radio-collared cows were living in the forest in small groups of up to 15 specimen. The lack of a correlation between the size of home ranges, mean daily temperature and the sum of rain-fall during vegetative seasons may be due to the fact that weather conditions in the years examined did not significantly affect food abundance in the Forest.

Studies carried out in the years 1977-1982 by direct observations of animals during the daytime showed that the size of cows' home ranges averaged $47 \mathrm{~km}^{2}$ (Krasińska et al. 1987), being smaller than the mean size of home ranges of radio-collared cows $\left(69 \mathrm{~km}^{2}\right)$, but still within the lower part of the range. The differences may be due to the application of another method. The studies based on radio-collared bison localization are more representative, investigating animals from different parts of the Polish and Belarussian populations. In both parts of the Frest, one mixed group of bison occupies a range amounting to $100 \mathrm{~km}^{2}$.

European bison are a gregarious animal, which in the snow-free season roams within its home range to use food resources most effectively. In the case of bison living in mixed groups, movements are mostly determined by foraging activity. A rotational pattern of area penetration ensures the optimal use of food resources ard allows regeneration of the herb layer. European bison only sporadically move beyond their permanent habitat. By contrast, the American bison undertake seasonal migrations, moving to qualitatively different refuges (Tempany and Cooper 1976). Thus, home range areas of the American bison are frequently far more extensive than those of the European bison. For instance, American bison cows from the population at Badlands (USA) occupied ranges covering $69-143 \mathrm{~km}^{2}$, bit spatial overlap was similar to that of the European bison, 58-68\% (Berger and Cunningham 1994). Ranges of American bison cows in the isolated population on Senta Catalina Island (USA) were 40 and $68 \mathrm{~km}^{2}$ (Lott and Minta 1983), and those of cows from the Henry Mountains population amounted to $52 \mathrm{~km}^{2}$ (Van Vuren 1883). Home ranges of wood bison from Mackenzie Bison Sanctuary (Canada) were considerably larger than those of the European bison, the mean adult cows' range being $1240 \mathrm{~km}^{2}$ (in areas providing significantly less available forage) and $395 \mathrm{~km}^{2}$ (in areas with more available forage) (Larter and Gates 1994).

For American bison cows, which often live in large herds, food is the most inportant factor determining the size of home ranges (Larter and Gates 1994). Likewise with the European bison, home range size in the snow-free period is related to the food abundance in their habitats, which is reflected in such diverse habitats as forest and meadow. In the Białowieża Forest, no significant differences wre observed in the period of May-July in the size of home ranges between mixed gioups feeding in the forest in the Polish and Belarussian populations, although in the Belarussian part coniferous types of forest predominate. However, in the B:larussian part, mixed groups living in the forest are significantly smaller than those inhabiting deciduous and mixed deciduous forests in the Polish part 
(Krasińska et al. 1997b). In the Belarussian part, open areas (meadows and large deforested glades covered in grass) play an important role in the foraging of bison and other ungulates (Korochkina and Bunevich 1980, Korochkina and Kochko 1982). The rich food resources of meadows and glades provide food for large bison groups, whose size (on average 23 individuals, maximum 140) is significantly larger than that of the groups living in the forest in the Polish and Belarussian part. In the period of August-October 1994-1998, mixed groups of 25-70 bison from the Belarussian population stayed on mown meadows, and they home ranges were two-fold smaller than those exploited by smaller mixed groups, foraging in the forest in the Polish part.

The earlier study, carried out by direct observations of animals during the daytime in the years 1976-1990, showed that the size of bulls' summer home ranges averaged $23 \mathrm{~km}^{2}$ (Krasińska and Krasiński 1995), the value being three times lower than the mean size of home ranges of radio-collared males, but still within the lower part of the range. The differences may result from the application of another method. Radio-collared bulls, coming from the two populations of bison in the Białowieża Forest occupy ranges averaging $70 \mathrm{~km}^{2}$, which in the case of peripheral bulls can reach the maximum of $150 \mathrm{~km}^{2}$. The size of bulls' home ranges, as in earlier studies, was age-dependent. The largest home ranges are occupied by older adult males (7-9 years old), taking parts in reproduction. The American wood bison bulls occupy substantially larger home ranges than European bison bulls. In the Mackenzie Bison Sanctuary in the Northwest Territory (Canada), bulls living in small groups occupied ranges averaging $435 \mathrm{~km}^{2}$ (younger adult bulls) and 170 $\mathrm{km}^{2}$ (older adult bulls). Access to mates was found to be the most important factor determining the size of home ranges of wood bison bulls (Larter and Gates 1994). Two bulls from the Polish population, which spent winter and early spring on the Forest periphery, occupied surprisingly large home ranges amounting to 136 and $151 \mathrm{~km}^{2}$. At the end of June they left the periphery, moved to the Forest centre inhabited by mixed groups and stayed there until the end of the rut. Their ranges in snow-free periods were significantly larger, compared with those of other bulls. Likewise, peripheral wood bison bulls occupied more extensive ranges than the other males (Larter and Gates 1994).

The fact that radio-collared European bison bulls living solitarily or in groups of 2-3 occupy home ranges of similar size as those of the mixed groups of 7-15 individuals indicates that the sexual activity has a stronger effect on the size of bulls home ranges than does food. Young adult radio-collared males (4-6 years old), which do not participate in reproduction, occupy the smallest ranges. Bulls from both age groups are sexually mature, but the younger bulls are not admitted by other ones to rutting cows that for behavioral reasons. A comparison of the overlap of bison home ranges indicates that ranges of cows and bulls are not defended throughout the year in the Białowieża Forest.

Summarizing we can state: (1) Permanent supplemental feeding of the bison delimits their natural foraging and affects the size and spatial distribution of their 
home ranges in winter. (2) The relationships created in large, winter aggregations affect the spatial distribution of summer home ranges of bison. (3) Bulls and cows show strong spatial fidelity in subsequent years. (4) The home ranges of bison from both sexes are not defended, and overlap extensively. (5) Participation in reproduction determines the size of bulls home ranges. (6) Differences of habitat (forest or meadows) affect the size of the ranges of mixed groups.

Acknowledgements: The authors wish to express their sincere appreciation to the staff of the Białowieża National Park for their help in bison marking, and to M. Szuma, A. Arasim and P. Kordecki from the Mammal Research Institute, Polish Academy of Sciences, for their assistance in marking and observations of radio-collared bison. We are most grateful to $\mathrm{K}$. Zub for preparing the figures. Many thanks are due to dr B. Jędrzejewska (MRI PAS) and to dr M. Meagher from the Yellowstone National Park USA for their critical reading and valuable comments on this paper, also to D. Glasson (American Peace Corps) for corrected the English. The study was financed by the grant KBN No 6PO4F 04910 .

\section{References}

Berger J. and Cunningham C. 1994. Bison: mating and conservation in small populations. Columbia University Press, New York: 1-282.

Bunevich A. N. 1991. [Results of displacements of the European bison on the area of the Białowieża Forest]. Zapovedniki Belorusi, Issledovaniya 15: 98-109. [In Russian]

Bunevich A. N. 1994. [Characteristics of the European bison population in the east part of the Białowieża Forest]. Sovremennye problemy okhrany zubra. Materialy mezhdunarodnogo simpoziyuma po zubru. IPP Ministerstva ekonomiki Respubliki Belarus, Minsk: 35-39. [In Russian]

Bunevich A. N. and Kochko F. P. 1988. [Dynamics and structure of the European bison population in the Białowieża Forest]. Populatsionnye issledovaniya zhivotnykh v zapovednikakh. Sbornik nauchnykh trudov, Nauka, Moskva: 96-114. [In Russian]

Hedemann O. 1939. L'histoire de la foret de Białowieża (jusqu'a 1798). Institut de recherches des firest domaniales. Travaux et comptes rendus, Serie D 41: 1-310. [In Polish with French summary]

Jurkevich I. D. and Geltmann W. S. 1965. [Geography, typology and distribution of forest flora of Belarus]. Nauka i Tekhnika, Minsk: 1-288. [In Russian]

Kertsov G. 1903. [The Białowieża Primeval Forest]. A. Marks, Sankt Petersburg: 1-410. [In Russian]

Kcrochkina L. N. 1973. [Distribution of the European bison population in the Białowieża Forest]. Belovezhskaya Pushcha, Issledovaniya 7: 148-164. [In Russian]

Kcrochkina L. N. and Bunevich A. N. 1980. [Influence of reforested glades on ungulates' feeding base in the Białowieża Forest]. Zapovedniki Belorussi, Issledovaniya 4: 109-116. [In Russian]

Korochkina L. N. and Kochko F. P. 1982. [Dynamics of free-ranging population number of the European bison in the Białowieża Forest]. Zapovedniki Belorussi, Issledovaniya 7: 52-59. [In Russian]

Kissak S. 1998. [Monitoring and estimation of game and protected mammals as the base of management plan and protection of the Białowieża Forest biodiversity. Report for 1998]. IBL, Zakład Lasów Naturalnych, Białowieża: 1-53. [In Polish]

Krasińska M., Caboń-Raczyńska K. and Krasiński Z. A. 1987. Strategy of habitat utilization by European bison in the Białowieża Forest. Acta Theriologica 32: 147-202.

Krasinska M. and Krasiński Z. A. 1994. Spatial structure of the European bison population in the Polish part of the Białowieża Forest 1976-1993. Parki Narodowe i Rezerwaty Przyrody 13: 69-87. [In Polish with English summary]

Krasiniska M. and Krasiński Z. A. 1995. Composition, group size and spatial distribution of European bison bulls in Białowieża Forest. Acta Theriologica 40: 1-21.

Krasinska M., Krasiński Z. A. and Bunevich A. N. 1997a. Functioning of the European bison Bison bonasus bonasus population in the Polish and Byelorussian parts of the Białowieża Forest in 1976-1995. Chrońmy Przyrodę Ojczystą 53: 28-40. [In Polish with English summary] 
Krasińska M., Krasiński Z. A and Bunevich A. N. 1997b. Differentiation of the size of mixed groups of European bison populations depending on the habitats utilised in Białowieża Forest. Parki Narodowe i Rezerwaty Przyrody 16: 55-66. [In Polish with English summary]

Krasiński Z. 1967. Free living European bison. Acta Theriologica 12: 391-405.

Krasiński Z. A. 1978. Dynamics and structure of the European bison population in the Białowieża Primeval Forest. Acta Theriologica 23: 13-48.

Krasiński Z. A. 1983. The first 10 years of free breeding of bison in the Białowieża Primeval Forest 1952-1961. Parki Narodowe i Rezerwaty Przyrody 4: 39-50. [In Polish with English summary]

Krasiński Z. A., Bunevich A. N. and Krasińska M. 1994. Characteristics of the European bison populations in the Polish and Belarussian parts of the Białowieża Forest. Parki Narodowe i Rezerwaty Przyrody 13: 25-67. [In Polish with English summary]

Larter N. C. and Gates C. C. 1994. Home range size of wood bison: effects of age, sex, and forage availability. Journal of Mammalogy 73: 142-149.

Lott D. F. and Minta S. C. 1983. Random individual association and social group instability in American bison (Bison bison). Zeitschrift für Tierpsychologie 61: 153-172.

Sokołowski A. 1997. Conservation of natural resources of Białowieża. Chrońmy Przyrodę Ojczystą 53: 18-26. [In Polish with English summary]

Tempany I. R. and Cooper S. 1976. Bison concentrations and distributions on primary ranges, October 1974 - October 1976. [In: Wood Buffalo National Park Bison Research 1972-76. 1976. Anuual Report. J. G. Stelfox, ed]. Canadian Wildlife Service, Parks, Canada, Edmonton: 1-11.

Van Vuren D. 1983. Group dynamics and summer home range of bison in southern Utah. Journal of Mammalogy 64: 329-332.

Received 24 June 1999, accepted 15 December 1999. 